\title{
Graham Price, Oscar Wilde and Contemporary Irish Drama: Learning to Be Oscar's Contemporary
}

\section{Thierry Dubost}

\section{(2) OpenEdition \\ 1 Journals}

\section{Electronic version}

URL: https://journals.openedition.org/etudesirlandaises/8966

DOI: 10.4000/etudesirlandaises.8966

ISSN: 2259-8863

\section{Publisher}

Presses universitaires de Caen

\section{Printed version}

Date of publication: 24 September 2020

Number of pages: 120-122

ISSN: 0183-973X

\section{Electronic reference}

Thierry Dubost, "Graham Price, Oscar Wilde and Contemporary Irish Drama: Learning to Be Oscar's

Contemporary", Études irlandaises [Online], 45-1 | 2020, Online since 24 September 2020, connection on 18 November 2022. URL: http://journals.openedition.org/etudesirlandaises/8966 ; DOI: https://doi.org/ 10.4000/etudesirlandaises.8966

\section{(c) (i) (2)(2)}

Creative Commons - Attribution-NonCommercial-ShareAlike 4.0 International - CC BY-NC-SA 4.0 https://creativecommons.org/licenses/by-nc-sa/4.0/ 
quotations are a means to get into the various works. Detailed passages also focus on Irish literary networks and on the wide intertextualities that are at stake in those works. For instance, the opening chapter tackles W. B. Yeats's major influence on Samuel Beckett, and the second one sheds light on his influence on Plunkett's Strumpet City, while chapter three is the occasion to see how close and entangled the Irish literary world was in 1948, when authors like Austin Clarke, Louis MacNeice, Father O'Connor, John Hewitt organised or attended to Yeats's burial in Ireland. This historical episode is also a good occasion for Dawe to give the larger historical and religious backgrounds of that time, when everyone seemed happy to have Yeats back again in Ireland.

This personal and critical approach provides entertainment and insight but sometimes lacks a unified approach: the chapters were often first academic lectures or chapters in various books and there is no clear definite argument. The place dedicated to women's voices is another complex component of the book. Dawe focuses on Eiléan Ní Chuilleanáin or Eavan Boland, or devotes a whole compelling chapter to Dorothy Molloy, Michael O'Sullivan or Leontia Flynn in "Bashō, the River Moy and the Superser" (p. 206-216). He also sheds light on Bobby Sands's interest in Ethna Carbery's nationalist poems, criticising the leader of the IRA for his romantic reveries and the "grotesque parallels" (p. 186) he drew between Long Kesh prisoners and the Jews perishing in the gas chambers. Yet, we can feel his greater ease when writing about generations of fellow poets and teachers in Dublin, in a chapter about John Berryman and his friends, or about the poems and relationships of Derek Mahon and Seamus Deane.

An important element of these essays is also Dawe's advice about new academic ground and research, or possible publications. His personal voice as publisher of The Younger Irish Poets blends with proposals about new possible studies on Ulster Scots for example or about the necessity to work on an edition of all Deane's poems in order to have a global view of his poetic achievement... There is no gratuitous esotericism or jargon in these entertaining essays, but personal scholarly advice and perspectives on Irish writers whose fame is already established or will be so very soon according to Dawe, who manages to bring together a wide variety of Irish poets, playwrights and novelists.

Florence SCHNEIDER

\section{Graham Price, Oscar Wilde and Contemporary Irish Drama: Learning to Be Oscar's Contemporary, London, Palgrave Macmillan, 2018, 249 p.}

Oscar Wilde and Contemporary Irish Drama: Learning to Be Oscar's Contemporary is a valuable book for anyone who wants to have a broad view of the ways in which contemporary Irish drama (defined here as post 1964 Philadelphia Here I Come!) 
resonates with Wildean ways. The book title could prove misleading if one only viewed Oscar Wilde as a playwright, since Graham Price's investigation also takes into account multiple aspects of Wilde's life as well as his work as a critic or theorist. Price notes that for decades Oscar Wilde was excluded from the Irish literary canon, but shows that moving from "what James Joyce called 'a court jester to the English"” (p. 3), he has gradually been recognised by some major critics as an Irish writer. Price's intent is to reinforce this outlook, and his main purpose seems to show that "Wilde's shadow looms large over theatre" (p. 1).

The introduction analyses the Beckett / Wilde connection, while the last chapter "Being Wild(ean) in the twenty-first century" (p. 221-236) highlights the influence of Wilde on the works of Martin McDonagh and Mark O'Halloran. The other chapters each deal with one major Irish playwright. The list is as follows: Brian Friel, Tom Murphy, Thomas Kilroy, Frank McGuinness and Marina Carr.

To some extent, the opening statement about the Friel / Wilde connection "Any attempt to argue for the influence exerted by Oscar Wilde upon the dramatic works of Brian Friel will be a challenging (albeit rewarding) prospect" (p. 36) resonates with Price's whole research project. The importance of doubling in Friel's dramatic works leads Price to stress the proximity of Philadelphia, Here I Come! to The Importance of Being Earnest. This confluence may seem minimal, and Price's focus on intertextual evidence between the two authors is not always convincing, but a study of Wilde's legacy upon Friel remains stimulating. As is the case for Friel, the Murphy/Wilde connection is not immediately striking, but Price interestingly contrasts The Importance of Being Earnest as a fratricidal comedy, with its tragic echoes in A Whistle in the Dark. Starting from detailed analyses of Murphy's plays, Price defines Murphy as an ethical moralist, viewed in Wildean terms. As is the case for Friel, the reader faces interesting textual analyses, and is willing to be convinced, but while there are undeniable meeting points between the two creators, it remains somewhat difficult - especially as Price extends his reflection to other playwrights or other aspects of Murphy's plays - to regard Murphy as learning to be Wilde's contemporary.

Unsurprisingly, the chapter dealing with the Kilroy/Wilde connection (p. 107142) proves more convincing than the previous ones. The Secret Fall of Constance Wilde, My Scandalous Life as well as Double Cross illustrate the links between the two authors, while the homosexual character in The Death and Resurrection of Mr Roche, or the dramatist in Tea and Sex and Shakespeare highlight Wildean proximities in Kilroy's works. In multiple ways, intertextual evidence (combined with reminders of Field Day's agenda) shows how Wilde's plays permeate Kilroy's works. The chapter devoted to Frank McGuinness (p. 143-184) examines how the Wildean aesthetic resonates with the plays. As the playwright himself has repeatedly stated, Wilde's influence on his works cannot be challenged. Price convincingly shows meeting points (through comedy, wit, gender issues or the relationship between language and reality) between The Importance of Being Earnest, "The Decay of Lying" or "De Profundis" and Observe the Sons of Ulster Marching towards the Somme, Carthaginians, Someone Who'll Watch over Me and Dolly West's Kitchen. 
As for Marina Carr (p. 185-220), focusing on Portia Coughlan, By the Bog of Cats, and Woman and Scarecrow, Price's analysis is stimulating. He links Carr's plays with Wilde's Salomé, through the status of her tragic heroines, whom he views as Dionysian women due to their rejection of distinctions between nature and humanity, as well as an opposition between masculine and feminine usage of language. Concluding with more recent plays, Price shows how Carr has refashioned Wildean aesthetics to define her own.

Oscar Wilde and Contemporary Irish Drama: Learning to Be Oscar's Contemporary has a clear, balanced structure, which paradoxically might be its weak point. Indeed, although it is well documented, one could argue that it devotes too much space to Friel and Murphy, without putting forth very convincing points. On the other hand, in view of what Price has to say about Kilroy, McGuinness or Carr, one feels that longer chapters on them would have given a greater impact to the book.

Thierry Dubost

\section{Okan Ozseker, Forging the Border: Donegal and Derry in Times of Revo- lution, 1911-1925, Newbridge, Irish Academic Press, 2019, 302 p.}

Alors que les négociations sur le Brexit n'en finissent pas de buter sur la question de la frontière irlandaise et que la perspective d'une seconde partition de l'Irlande ne peut être écartée, cet ouvrage sur la période révolutionnaire dans les comtés de Donegal et de Derry permet de mieux cerner les enjeux de la division territoriale dans cette partie de l'île, ainsi que les événements qui y conduisirent et la manière dont la population y réagit il y a un siècle.

Si la décennie des commémorations a donné lieu à de nombreuses publications sur la période 1911-1925, il s'agit ici d'une approche relevant de l'histoire régionale dans un territoire qui peut être considéré comme un "microcosme» de la question d'Irlande à l'époque (p. 202). Il présente par ailleurs des spécificités intéressantes, telles que la présence d'une forte communauté unioniste radicale dans le comté de Londonderry, un Donegal qui était un bastion du nationalisme conservateur, le statut hautement symbolique de la ville de Derry/Londonderry revendiquée par les deux camps, et un impact particulièrement important de la partition pour d'évidentes raisons géographiques. De manière inattendue cependant, le Donegal se caractérisa par un niveau de violence plus faible qu'ailleurs en Irlande, même si le comté de Derry connut bien des émeutes, affrontements et exactions, mais à une échelle moindre qu'à Belfast.

Lors de la crise du Home Rule, en janvier 1913, l'élection partielle de Derry fut perçue par tous comme un test décisif, tant en Irlande qu'en Grande-Bretagne (p. 37-38). Même si elle se trouvait dans le comté de Londonderry, elle était 